\title{
Early Childhood Care In Sambas Muslim Family: Cultural And Religious Influences
}

\author{
Bayu Suratman ${ }^{1}$, Nurjannah ${ }^{2}$ \\ 1,2Sunan Kalijaga Islamic State University, Yogyakarta, Indonesia \\ 1bayuseladu@gmail.com \\ 2nurjannah@uin-suka.ac.id
}

\section{Article History: Abstract:}

Submitted:

2021-02-08

Accepted:

2021-05-08

Published:

2021-08-01
This article reports an in-depth study on early childhood care in Sambas Malay Muslim family. This research incorporated a qualitative method with a descriptive approach through observations and interviews with parents and Sambas local figures. The findings indicate the influence of local culture and religious values on Sambas Muslim parenting style. More specifically, this study showed that parenting practices of Muslim Sambas Malay parents are carried out through the tradition of pantang larang and kemponan. Pantang larang and kemponan become parts of collective memory so that they become social educative traditions in early childhood care in the Muslim Sambas Malay family.

Keywords: Parenting; Muslim Family, Malay Sambas. 


\section{Introduction}

As homosocial, children need communities for their everyday activities. However, parents often do not engage in children's daily activities. Children receive little attention from parents that is crucial for their emotional needs ${ }^{1}$. Guidance and parenting provided by parents to children should be compassionate and show good relationships in the family environment. In addition, the family environment should avoid actions that could cause the children stressed and intimidated. Parenting will have an impact when the children become adults. Moreover, parenting in the family environment also affects the socio-emotional development of the child. As such, parenting performed by the mother affects the relationship between the

${ }^{1}$ Chun Chen, Zhenjie Yuan \& Hong $\mathrm{Zhu}$, "Playing, parenting and family leisure in parks: exploring emotional geographies of families in Guangzhou Children's Park, China," Children's Geographies 18, no. 4 (2020): 463-76, https://doi.org/10.1080/14733285.2 019.1676879 . parent and the child. Moreover, the care of a father and mother each have the same benefits in aspects of child development. ${ }^{2}$

The family environment is where children are raised and have long influences: emotions, brain development, empathy, mental and physical health. The characteristic of the parenting environment is to minimize the climate that will damage the physical and spiritual development of the child. The family environment must be able to build the child's character from an early age to adulthood. In essence, the family and school environments have an equally important war in building children's development. ${ }^{3}$

2 Van Lissa, Caspar J \& Keizer, Renske, "Mothers' and fathers' quantitative and qualitative parenting in relation to children's emotional adjustment: A betweenand within-family investigation," Developmental Psychology 56, no. 9 (2020):

1709-22, https://doi.org/10.1037/dev000104 2.

3 James N. Kirby, "Nurturing Family Environments for Children: Compassion-Focused Parenting as a Form of Parenting Intervention," Education Sciences 10, no. 1 (2020): 115, 
Moreover, some emotions are formed by the quality of interpersonal interactions during the child's developmental stages. Parentchild relationships are the most influential form of early social interakis. Therefore, parenting practices should pay attention to aspects of affection so that parents and children will be closer. 4

No less important, parents' parenting to children is inseparable by religious and cultural factors. ${ }^{5}$ Like, what happens in India between education, religion, and caste is intertwined. The influence is up to the stage of children enrolling in schools that are influenced by community norms. ${ }^{6}$. Based on

https://doi.org/10.3390/educsci100 10003.

4 Gillian England-Mason \& Andrea Gonzalez, "Intervening to shape children's emotion regulation: A review of emotion socialization parenting programs for young children," Emotion 20, no. 1 (2020): 98-104,

https://doi.org/DOI:10.1037/emo0 000638.

5 Usang M Assim \& Julia SlothNielsen, African Human Rights Law Journal 14, no. 2 (2014): 322-45.

6 Vani K. Borooah \& Sriya Iyer, "Vidya, Veda, and Varna: The influence of religion and caste on education in rural India," The Journal research conducted by Valarie Kin how the religious aspects of a father affect the quality of engagement with his children. A religious father is involved and has a good relationship with the child. Therefore, parents should have a spiritual understanding that is in the household ark because the religious factors of parents affect the development of early childhood to adulthood.7

In addition to the religious factors, parenting is a combination of innate and the child's environment. Although, in principle, a child has been given a gene of faith by God in the form of a brain that is true when told by others to us, especially if the idea appeals to fantasies and desires buried in man. Man is born with a tendency to believe in what others say

of Development Studies 41, no. 8 (2005): 1369-1404, https://doi.org/10.1080/002203805 00186960.

7 Valerie King, "The Influence of Religion on Fathers' Relationships With Their Children," Journal of Marriage and Family 65, no. 2 (2004): 382-95,

https://doi.org/10.1111/j.17413737.2003.00382.x. 
and man does not have time to question every piece of information he receives because the brain contains corridors, labyrinths, and hidden spaces changing direction. The brain constantly rearranges the cognitive information it retains, predicting new meanings and beliefs in every experience it receives. This belief permeates the deep levels of the human psychosomatic system, mind, brain, nervous system, endocrine system, and muscles. All this affects human beings acting, speaking, and thinking according to the firmly held belief systems of belief. 8

Therefore, the importance of religion and culture in the family environment towards early childhood care is one of the determining factors in child development. Parents must instill religious values that are embraced to the child and cultural values in the family environment such as, in the Sambas Malay community that instills

8 Andrew Newberg \& Mark Robert Waldman, Born To Believe: Gen Iman Dalam Otak (Bandung: Mizan Pustaka, 2013). religious values through a culture maintained in the family environment. The parenting done by Sambas Malay people is part of the model of family care that is done to children. The upbringing carried out by the Sambas Malay Muslim family included elements of Islam and Malay culture. Of course, this is interesting because, on the other hand, Sambas Malay people still maintain locality values but also practice parenting through Islamic values.

This research model of early childhood parenting in Muslim family environment has been widely done such as Supaat \& Salmah Fa'atin ${ }^{9}$ in their research entitled "The Muslim Millenial Family Typology: the role of Muslim family circumflex to avoid parent's violent behavior against children in Indonesia." This study

9 Supaat \& Salmah Fa'atin, "The Muslim Millennial family typology: the role of Muslim family circumflex model to avoid parents' violent behavior against children in Indonesia," Indonesian Journal of Islam and Muslim Societie 9, no. 1 (2019): 57-81, https://doi.org/DOI: https://doi.org/10.18326/ijims.v9i1. 57-81. 
examines the shifting function of Muslim families in the millennial era sociological perspective. This study discusses the circumstance model of the family and marriage pattern system, where the ideal Muslim family does not commit violence to children. This study examined the types of Muslim family patterns in the millennial era based on the circular model: the dimensions of family closeness, the dimensions of family adaptability, and the dimensions of communication. The study mentioned three muslim family types in the millennial era, first extreme, middle range, and balanced. In addition, the research conducted by Michela Franceschelli \& Margaret O'Brien ${ }^{10}$ entitled "Islamic Capital' and Family Life: The Role of Islam in Parenting". The study explored habitus and family environments in south Asian Muslim

10 Michela Franceschelli \& Margaret O'Brien, "'Islamic Capital' and Family Life: The Role of Islam in Parenting," Sage Journal 48, no. 6 (2014): 1190-1206, https://doi.org/10.1177/003803851 3519879 . communities in the UK where parenting practices are carried out in decline or between generations to instill values in children. This study showed that parents mobilize families to transmit a sense of morality, education and strengthen family relationships. This research is interesting because parenting is done based on the values instilled by religious families. The characteristics of religiously devout families are contained in the writings of David C. Dollahite \& Loren D. Marks"11 entitled "A Conceptual Model of Family and Religious Processes in Highly Religious Families". This research shows that the characteristics of religiously obedient families have characteristics, namely: relying on god's word for support, guidance, and strength, purifying the family by carrying out religious orders at home, resolving conflicts with prayer,

11 David C. Dollahite \& Loren D. Marks, "A Conceptual Model of Family and Religious Processes in Highly Religious Families," Review of Religious Research 50, no. 4 (2009): 373-91, https://doi.org/www.jstor.org/stab le/25593754. 
repentance, and forgiveness, loving and loving others in the family, following religious community activities, not doing what is prohibited by religion, sacrificing time and money, maintaining spiritual obedience through teaching, examples, and discussions, obey God, the Prophet, parents, and put faith and family above personal interests.

\section{Method}

This study focuses on the model of early childhood care in the Malay Muslim family sambas. This paper incorporates qualitative research with a descriptive approach where the data is obtained from interviews and observations. The interview was conducted with Sambas local figures, Sambas Malay Muslim families, and key experts comprising 11 people as follow:

\begin{tabular}{|l|l|l|}
\hline No & \multicolumn{1}{|c|}{$\begin{array}{c}\text { Name } \\
\text { (Pseudonym) }\end{array}$} & Position \\
\hline 1. & Sosi & Parent \\
\hline 2. & Sanimah & Parent \\
\hline 3. & Ratni & Parent \\
\hline 4. & Hendri & Parent \\
\hline 5. & Agus & Parent \\
\hline 6. & Kartini & Parent \\
\hline 7. & Muin Irkam & $\begin{array}{l}\text { Cultural } \\
\text { practition } \\
\text { er }\end{array}$ \\
\hline
\end{tabular}

\begin{tabular}{|l|l|l|}
\hline 8. & Adnan Mahdi & $\begin{array}{l}\text { Sambas } \\
\text { Research } \\
\text { er }\end{array}$ \\
\hline 9. & Yusriadi & $\begin{array}{l}\text { Sambas } \\
\text { Research } \\
\text { er }\end{array}$ \\
\hline 10. & Asnawi & $\begin{array}{l}\text { Secretary } \\
\text { of } \\
\text { Sambas } \\
\text { Ulama } \\
\text { Associati } \\
\text { on }\end{array}$ \\
\hline 11. & Sipnih & $\begin{array}{l}\text { Head of } \\
\text { Sambas } \\
\text { Ministry } \\
\text { of } \\
\text { Religious } \\
\text { Affairs }\end{array}$ \\
\hline
\end{tabular}

The data collection method also involves direct observations at the research site in rural Sambas Regency, an administrative area in West Kalimantan.

\section{Result and Discussions Sambas Muslim Family Identity}

The majority of people in Sambas Regency are Malay, and $87 \%$ are Muslim from the entire Sambas population (interview of Mr. Sumar'in Asnawai, Secretary of MUI Sambas). Muslims in Sambas have moderate characteristics where they accept differences in background, ethnicity, and

6 Nadwa: Jurnal Pendidikan Islam 
different religions. ${ }^{12}$ In addition, Sambas Muslims also still maintain cultural values that have existed since their ancestors. Malay Sambas and Islam are inseparable units. Hermansyah and Yusriadi said that Malay and Islam are synonyms, and the two are bound to each other. When discussing Malay Sambas, it will indirectly discuss Islam. ${ }^{13}$

Malay

Kalimantan,

Sambas, has the same typology that maintains old traditions or habits in everyday life. Nevertheless, Sambas Malay is a devout

12 Zaenuddin Hudi Prasojo, Elmansyah, \& Muhammad Sahrin bin Haji Masri, "Moderate Islam and the Social Construction of MultiEthnic Communities in the Hinterland of West Kalimantan." Indonesian Journal of Islam and Muslim Societies," Indonesian Journal of Islam and Muslim Societie 9, no. 2 (2019): 218-19.;Erwin Mahrus, Zaenuddin Hudi Prasojo, \& Busro, "Messages of Religious Moderation Education in Sambas Islamic Manuscripts," Madania: Jurnal Kajian Keislaman 24, no. 1 (2020).

13 Yusriadi, Identitas Orang Melayu di Hulu Sungai Sambas (Pontianak: IAIN Pontianak Press, 2017).p.1-3.; Hermansyah, Islam dan Melayu di Borneo (Pontianak: IAIN Pontianak Press, 2015).p.1.
Muslim where the teachings of Islam are inseparable in everyday life. ${ }^{14}$ Islam and Sambas Malay culture have become hybrids and fused in the joints of life. Thus, the tradition carried out by the Sambas Malays wrapped in Islamic teachings makes the tradition run lively. 15. Sambas Malay people also have strong emotional ties to fellow Sambas Malay community. Activities carried out inviting crowds such as, weddings, thanksgiving, circumcision, religious activities, farming, and others are carried out in tandem. ${ }^{16}$

14 Yusriadi, Memahami Kesukubangsaan di Kalimantan Barat (Pontianak: STAIN Pontianak Press, 2008).; Hermansyah, Ilmu Gaib di Kalimantan Barat (Jakarta: Kepustakaan Populer Gramedia, 2010).

15 Syamsul Kurniawan, “Globalisasi: Pendidikan Karakter, dan Kearifan Lokal yang Hybrid Islam Pada Orang Melayu Kalimantan Barat," Jurnal Penelitian 12, no. 2 (2018).

16 Syamsul Kurniawan \& Bayu Suratman, "Bertani Padi Bagi Orang Melayu Sambas: Kearifan Lokal, Nilai-Nilai Islam, dan Character Building," Analisis: Jurnal Studi Keislaman 18, no. 2 (2018): 190-91.; Bayu Suratman \& Syamsul Kurniawan, "Tudang Sipulung In Muslim Community Of Peniti Luar (Identity, Islamic Value, And 
When the Sambas Malay people ordained themselves as Muslims, the identity attached to the Sambas Malay community was the Mosque. The number of houses of worship in Sambas Regency includes:

Tabel. 1

Number of Houses of Worship in Sambas

\begin{tabular}{|c|c|l|}
\hline No & $\begin{array}{c}\text { Houses of } \\
\text { worship }\end{array}$ & \multicolumn{1}{|c|}{ Total } \\
\hline 1. & $\begin{array}{c}\text { Mosque } \\
\text { and Surau }\end{array}$ & $\begin{array}{l}\text { 687 and } 385 \\
\text { buildings }\end{array}$ \\
\hline 2. & $\begin{array}{c}\text { Catholic } \\
\text { Church and } \\
\text { Chapel }\end{array}$ & $\begin{array}{l}75 \text { and 10 } \\
\text { buildings }\end{array}$ \\
\hline 3. & $\begin{array}{c}\text { Christian } \\
\text { Church }\end{array}$ & $\begin{array}{l}93 \\
\text { buildings }\end{array}$ \\
\hline 4. & Monasteries & $\begin{array}{l}168 \\
\text { buildings }\end{array}$ \\
\hline 5. & Tempel & 2 buildings \\
\hline 6. & Pagoda & $\begin{array}{l}45 \\
\text { buildings }\end{array}$ \\
\hline
\end{tabular}

Source: Mr Sipni, head of the ministry of religious affairs, Sambas

Character Building)," Jurnal Khalustiwa: Journal of Islamic Studies 9, no. 1 (2019): 71-73. Abdul Wahab, "Islamic Values of Social Relation in Besaprah Tradition of Sambas Society: The Case of Post-Conflict Malay-Madura in 1999-2007," Jurnal Walisongo: Jurnal Penelitian Sosial Keagamaan 25, no. 2 (2017): 383400.;Moh.Haitami

"Kontribusi Upacara Adat Mendirikan dan Pindah Rumah Terhadap Nilai Pendidikan Islam," Jurnal Walisongo: Jurnal Penelitian Sosial Keagamaan 21, no. 2 (2013): 331-36.
Therefore, seeing a large number of mosque buildings in Sambas makes the Mosque a part of Sambas Malay identity. The mosque is not just a house of worship. Still, many traditional community activities carried out in the Mosque. ${ }^{17}$ The mosque is an inseparable part of sambas Malay life because of the mosque between houses of worship and the means of implementing cultural traditions. Another identity attached to the Sambas Malay people, is the home ${ }^{18}$. Sambas Malay house model is generally built with construction on stilt and formed by wood as the main material. $^{19}$

17 Masmuri \& Bayu Suratman, "Revitalisasi Masjid Dalam Membangun Karakter Pada Komunitas Melayu Sambas," jurnal intizar 25, no. 1 (2019).

18 Yusriadi, Identitas Orang Melayu di Hulu Sungai Sambas.

19 Zairin Zain \& Indra Wahyu Fajar, "Tahapan Konstruksi Rumah Tradisional Suku Melayu di Kota Sambas Kalimantan Barat," Jurnal Langkau Betang 1, no. 1 (2014): 18.; Zairin Zein, "The structural System of Tradisional Malay Dwellings in Sambas Town, West Kalimantan Indonesia," International Journal of the Malay World and Civilisation 30, no. 1 (2012): 139-158. 
Sambas Malay house the religion of society and model extends backward forms a culture in with varying lengths usually determining one's way of life. about 10-20 meters. As for the entrance of the Sambas Malay people's house on the side of the river there are various kitchens facing the street and terraces facing the river. Some sambas Malay houses visited by writers are decorated with calligraphy in the form of writings of Muhammad and Allah. The location of Islamic calligraphy is stored in the living room. Some sambas Malay houses are also decorated with pictures of the sultan of Sambas, who influences the Sambas area. Therefore, the Sambas Malays appreciated the leaders and sultans who once led the Sambas kingdom. The proximity of Islam and Sambas Malays makes local and Islamic values melt into the daily lives of Sambas Malays. The Identity of Muslim and Malay Sambas is not just a coincidence but there is a long process between Islam and Sambas Malay unites.

\section{Sambas Malay Muslim Family Parenting Model}

According to Jane Brooks, parenting is closely related to As for one of the cultures formed by culture, such as, do not drink alcohol and worship several times a day that is passed down to the child. Of course, cultural influences are also related to the identity that parents have. Culture in the family environment towards early childhood care is one of the determining factors in child development. Parents must instill religious values that are embraced to the child and cultural values in the family environment. ${ }^{20}$ In addition, the role of both parents who become the first madrasah for children must establish affection for the child. The task of parents is to create the atmosphere of the family education process so that it gives birth to a generation of intelligent and noble character as the basis when growing up..$^{21}$

20 Jane Brooks, The Process Of Parenting (Yogyakarta: Pustaka Belajar, 2011).;137.

21 M. Syahran Jailani, “Teori Pendidikan Keluarga dan Tanggung Jawab Orang Tua dalam Pendidikan Anak Usia Dini," Jurnal Nadwa: 
Pantang larang has the meaning of pantang or larangan used as a benchmark in life by the Sambas Malay people, whether related to rites or life cycles of Sambas Malay people such as birth marriage, and death. Pantang larang is an oral expression downhill and abstinence and prohibitions conveyed by the previous contain wisdom and value requirements ${ }^{22}$. The notion of pantang larang is derived from two words namely pantang and larang while in terminology abstinence (pantang) is a rule or even a prohibition (larangan) in actions carried out by individuals and groups of people considered taboo. Based on the results of the interview the author conducted to sambas researcher, Mr. Adnan Mahdi related to pantang larang, as follows:

"Pantang larang is a code of conduct. Why we need it because in the context of the child, the child is safe, born perfectly, and the process of education of

Jurnal Pendidikan Islam 8, no. 2 (2014): 245-56. the child achieves a goal that is guided both in the interests of parents, children and the world of the hereafter. The purpose of pantang larang is to maximize the purpose of parents in educating children. pantang larang is a positive because abstinence prohibits a rule. Pantang larang is a necessity and the goal is positive. Following the religious background of the parents. Pantang larang is mandatory in both the community and the elderly. For example, early childhood is forbidden to say dirty words, children are instructed to pray. Pantang larang is forbidden to achieve the expected goals, if we look at the interests and benefits must be mandatory in a family. Parents give a ban or frightening examples of children obeying parents". (Interview Mr. Adnan Mahdi Sambas Researcher).

Based on the statement above, pantang larang is a device of social prohibition 
Early Childhood Care In Sambas Muslim Family....

related to the culture that takes place in sambas Malay people who have been considered an obligation. In the context of early childhood education, abstinence is prohibited to be a way to educate children in the family environment to help maximize the objectives of parents in educating children. Of course what the Sambas Malay people do in educating children still use the element of local wisdom. Pantang larang from the sambas Malay parents teaches ethics to children related to daily life. Tabel. 2

Pantang Larang In Sambas Malay Early Childhood

\begin{tabular}{|c|c|c|c|}
\hline $\begin{array}{l}\mathbf{N} \\
\mathbf{o}\end{array}$ & $\begin{array}{c}\text { Statement } \\
\text { Pantang } \\
\text { Larang }\end{array}$ & $\begin{array}{l}\text { Cons } \\
\text { eque } \\
\text { nces }\end{array}$ & $\begin{array}{c}\text { Rational } \\
\text { ization }\end{array}$ \\
\hline 1. & $\begin{array}{l}\text { Prohibition } \\
\text { of not } \\
\text { sitting on a } \\
\text { pillow }\end{array}$ & $\begin{array}{l}\text { Caus } \\
\text { es } \\
\text { herni } \\
\text { a } \\
\text { disea } \\
\text { se }\end{array}$ & $\begin{array}{l}\text { Ethically } \\
\text { impolite } \\
\text { as } \\
\text { pillows } \\
\text { are } \\
\text { mostly } \\
\text { used for } \\
\text { the head }\end{array}$ \\
\hline 2. & $\begin{array}{l}\text { Standing } \\
\text { urine ban }\end{array}$ & $\begin{array}{l}\text { No } \\
\text { man } \\
\text { ners }\end{array}$ & $\begin{array}{l}\text { Health } \\
\text { will } \\
\text { cause } \\
\text { disease }\end{array}$ \\
\hline 3. & $\begin{array}{l}\text { It is } \\
\text { forbidden } \\
\text { to laugh at } \\
\text { cats }\end{array}$ & $\begin{array}{l}\text { Will } \\
\text { cause } \\
\text { lighti } \\
\text { ning } \\
\text { struc } \\
\text { k }\end{array}$ & $\begin{array}{l}\text { Appreci } \\
\text { ating } \\
\text { God's } \\
\text { creation }\end{array}$ \\
\hline
\end{tabular}

\begin{tabular}{|c|c|c|c|}
\hline 4. & $\begin{array}{l}\text { When } \\
\text { Looking at } \\
\text { the } \\
\text { Lightning } \\
\text { Say } \\
\text { taawudz }\end{array}$ & $\begin{array}{l}\text { Will } \\
\text { survi } \\
\text { ve } \\
\text { the } \\
\text { light } \\
\text { ning } \\
\text { strike }\end{array}$ & $\begin{array}{l}\text { Taking } \\
\text { Refuge } \\
\text { in the } \\
\text { name of } \\
\text { The } \\
\text { Lord }\end{array}$ \\
\hline 5. & $\begin{array}{l}\text { Prohibited } \\
\text { from } \\
\text { leaving the } \\
\text { house } \\
\text { when } \\
\text { heavy rains }\end{array}$ & $\begin{array}{l}\text { Will } \\
\text { be } \\
\text { hit } \\
\text { by a } \\
\text { ghost } \\
\text { attac } \\
\text { k }\end{array}$ & $\begin{array}{l}\text { Health } \\
\text { reasons } \\
\text { such as } \\
\text { avoiding } \\
\text { fever }\end{array}$ \\
\hline 6. & $\begin{array}{l}\text { Girls are } \\
\text { forbidden } \\
\text { to sit at the } \\
\text { door }\end{array}$ & $\begin{array}{l}\text { Won' } \\
\text { t get } \\
\text { a } \\
\text { partn } \\
\text { er }\end{array}$ & $\begin{array}{l}\text { Ethically } \\
\text { it's not } \\
\text { good for } \\
\text { girls to } \\
\text { sit in the } \\
\text { middle } \\
\text { of the } \\
\text { door }\end{array}$ \\
\hline 7. & $\begin{array}{l}\text { Prohibition } \\
\text { should not } \\
\text { overs step } \\
\text { over a } \\
\text { sleeping } \\
\text { person }\end{array}$ & $\begin{array}{l}\text { cause } \\
\text { disea } \\
\text { se } \\
\text { even } \\
\text { deat } \\
\text { h }\end{array}$ & $\begin{array}{l}\text { Ethically } \\
\text { it is not } \\
\text { good } \\
\text { whether } \\
\text { a child } \\
\text { over } \\
\text { sans a } \\
\text { parent }\end{array}$ \\
\hline 8. & $\begin{array}{l}\text { Ban on } \\
\text { passing } \\
\text { clothes }\end{array}$ & $\begin{array}{l}\text { Will } \\
\text { cause } \\
\text { head } \\
\text { aches }\end{array}$ & $\begin{array}{l}\text { Ethically } \\
\text { it's not } \\
\text { good to } \\
\text { go } \\
\text { through } \\
\text { a } \\
\text { clothesli } \\
\text { ne } \\
\text { because } \\
\text { there's a } \\
\text { lot of } \\
\text { clothes }\end{array}$ \\
\hline 9. & $\begin{array}{l}\text { Finishing } \\
\text { the rice } \\
\text { when } \\
\text { eating }\end{array}$ & $\begin{array}{l}\text { Cons } \\
\text { eque } \\
\text { ntly, } \\
\text { the } \\
\text { chick }\end{array}$ & $\begin{array}{l}\text { The } \\
\text { remaini } \\
\text { ng food } \\
\text { will be } \\
\text { wasted }\end{array}$ \\
\hline
\end{tabular}




\begin{tabular}{|c|c|c|c|}
\hline & & $\begin{array}{l}\text { en } \\
\text { will } \\
\text { die }\end{array}$ & \\
\hline 10. & $\begin{array}{l}\text { No } \\
\text { whistling } \\
\text { at home }\end{array}$ & $\begin{array}{l}\text { The } \\
\text { cons } \\
\text { eque } \\
\text { nces } \\
\text { of } \\
\text { not } \\
\text { getti } \\
\text { ng } \\
\text { the } \\
\text { suste } \\
\text { nanc } \\
\text { e }\end{array}$ & $\begin{array}{l}\text { Children } \\
\text { 's } \\
\text { morality } \\
\text { to } \\
\text { parents }\end{array}$ \\
\hline 11. & $\begin{array}{l}\text { Prohibition } \\
\text { of climbing } \\
\text { trees } \\
\text { during the } \\
\text { day }\end{array}$ & $\begin{array}{l}\text { Cons } \\
\text { eque } \\
\text { ntly } \\
\text { the } \\
\text { child } \\
\text { will } \\
\text { be } \\
\text { drop } \\
\text { ped } \\
\text { by a } \\
\text { ghost }\end{array}$ & $\begin{array}{l}\text { Rational } \\
\text { ly for } \\
\text { the } \\
\text { safety of } \\
\text { children }\end{array}$ \\
\hline 12. & $\begin{array}{l}\text { Prohibition } \\
\text { of oversit } \\
\text { on the } \\
\text { Qur'an }\end{array}$ & $\begin{array}{l}\text { Caus } \\
\text { es } \\
\text { herni } \\
\text { a } \\
\text { disea } \\
\text { se }\end{array}$ & $\begin{array}{l}\text { The } \\
\text { Quran } \\
\text { should } \\
\text { be } \\
\text { respecte } \\
\text { d }\end{array}$ \\
\hline 13. & $\begin{array}{l}\text { Prohibition } \\
\text { of sleeping } \\
\text { on your } \\
\text { stomach }\end{array}$ & $\begin{array}{l}\text { will } \\
\text { cause } \\
\text { moth } \\
\text { er's } \\
\text { deat } \\
\mathrm{h}\end{array}$ & $\begin{array}{l}\text { Health } \\
\text { will } \\
\text { disturb } \\
\text { the } \\
\text { lungs }\end{array}$ \\
\hline 14. & $\begin{array}{l}\text { Ban on } \\
\text { cutting } \\
\text { nails at } \\
\text { night }\end{array}$ & $\begin{array}{l}\text { will } \\
\text { cause } \\
\text { moth } \\
\text { er's } \\
\text { deat } \\
\text { h }\end{array}$ & $\begin{array}{l}\text { Logicall } \\
\text { y } \\
\text { worried } \\
\text { about } \\
\text { wrong } \\
\text { nail cut }\end{array}$ \\
\hline
\end{tabular}

Data Source: The results of an interview with Mr. A. Muin Irkam.
Based on the interviews conducted to informants, pantang larang develops in Sambas malay people that pantang larang contains procedures in addresing the rules and restrictions in acting. According to A. Muin Irkam in the daily life Sambas of Sambas malay people know the various advices, prohibitions, and restrictions given by the oldest people be it grandparents, grandmothers, fathers, and mothers, to be given to their children and grandchildren. If violated, there will be consequences for the parson. (interview with Mr. A. Muin Irkam, Sambas Malay Cultureman). Some Sambas Malays consider that pantang larang is used as a reference to build character value. Pantang larang is part of Sambas malay culture that is applied in educating early childhood. So that cultural values in the Family environment instilled in early childhood will become habitus in children's lives.

The upbringing carried out by the Sambas Malays through pantang larang is part of the internalization of cultural values to early childhood. According to Jane 
Brooks' view, culture is a set of values, beliefs, perspectives, rituals, and institutions of a group or population. The group can be small in shape such as neighbors, schools, or largeshaped communities such as race, ethnicity, and social status groups. Culture provides a way of seeing the world and togetherness with other influences, determining everyday feelings and behaviors. Culture is a dynamic impulse that responds to social, political, and economic events and shapes the event's meaning. Culture provides developmental niches that include (1) physical and social backgrounds for parents and children, (2) psychological characters valued by parents and children,

recommended behaviors for family members. Therefore, culture forms a wide range of parenting behaviors from the general values taught by parents to the real aspects of daily life where children can eat and sleep. ${ }^{23}$

Therefore, parenting in the Sambas Malay family is a

23 Jane Brooks, The Process Of Parenting.;127. cultural upbringing where there is a dynamic drive that responds to internalizing cultural beliefs and values. In addition, through pantang larang forbidden in the Malay family Sambas also practiced kemponan in parenting. The kemponan delivered by Chairil Effendy in Rizal Mustansyir defines kemponan as a state of wanting something that exists, but is not enjoyed to cause negative effects or excesses in the form of disasters. If you look at the term of Sambas kemponan language refers to the belief of the Sambas malay community to touch the food or drink offered, and if it is not done, it will get disaster. ${ }^{24}$ The importance of kemponan in the family life system of Malay Muslim Sambas was conveyed by Yusriadi, one of sambas researchers, as follows:

"After I observe why kemponan is important because it relates to the malay cultural system itself. First why there is

${ }^{24}$ Rizal Mustansyir, Kearifan Lokal Masyarakat Melayu Sambas Dalam Tinjauan Filosofis (Yogyakarta: Fakultas Filsafat UGM, 2015).134135. 
the term kemponan because malay people do not know the term pleasantries. So if a malay man offers something for example, offers him a drink instead of pleasantries to drink and he is really compassionate. And if not drunk then malay people will feel uncomfortable and small-hearted. In sambas malay culture one offers something not two or three times but once so there is no small talk. The bargaining culture is just one time". (interview with Mr. Yusriadi, Sambas researcher).

Kemponan and pantang larang are limited to unconsciously carried out traditions, but cultural values are internalized within the Sambas Malay Muslim family. Of course, the application of parenting is inseparable from the religion embraced, namely Islam. Based on the results of the interview If described into a diagram between parenting patterns, culture and Islam as follows:

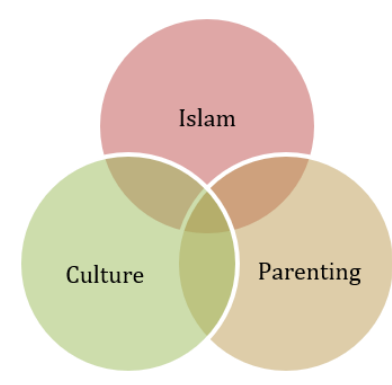

Diagam.1

Patterns of the relationship between parenting, culture, and Islam.

The pattern of relationship between parenting, culture, and Islam as in the diagram and the previous explanation is in line with the parenting carried out by the Sambas Malay Muslim family. For Sambas Malay Muslim families educating children in the tradition of kemponan and pantang larang has become one unity with cultural values that take place in people's lives. Kemponan has become a collective memory so that for parents the tradition of kemponan becomes devolution as a social education media means instilled cultural values. The tradition of kemponan is a form of appreciation for the intention of the host who presents a dish to be tasted by guests at least just touched a little to make the hearts of 
parents and guests happy when visiting.

\section{Conclusion}

The upbringing tradition in Sambas Malay Muslim family is part of the internalization of cultural and religious values in the early childhood care. Both cultural and spiritual values have been embedded into daily parenting style in Sambas Muslim Family. The parenting model in the form of pantang larang consists of restrictions and prohibitions influenced by local wisdom. In addition, the parenting model is also carried out in the Sambas Malay Muslim family through kemponan. Kemponan has become a social educative tradition in which cultural values are instilled through appreciation for the host's intention who presents a dish to the guest. This practice was applied in early childhood care where Sambas Malay Muslim parents teach their children gratitude for receiving and giving each other.
References

Abdul Wahab. "Islamic Values of Social Relation in Besaprah Tradition of Sambas Society: The Case of Post-Conflict Malay-Madura in 19992007." Jurnal Walisongo: Jurnal Penelitian Sosial Keagamaan 25, no. 2 (2017): 383-400.

Andrew Newberg \& Mark Robert Waldman. Born To Believe: Gen Iman Dalam Otak. Bandung: Mizan Pustaka, 2013.

Aslan. "Nilai-Nilai Kearifan Lokal Dalam Budaya Pantang Larang Suku Melayu Sambas." Jurnal Ushuluddin 161, no. 1 (2017).

Bayu Suratman \& Syamsul Kurniawan. "Tudang Sipulung In Muslim Community Of Peniti Luar (Identity, Islamic Value, And Character Building)." urnal Khalustiwa: Journal of Islamic Studies 9, no. 1 (2019): 71-73.

Chun Chen, Zhenjie Yuan \& Hong Zhu. "Playing, parenting and family leisure in parks: exploring emotional geographies of families in Guangzhou Children's Park, China." 
Children's Geographies 18, no. 4 (2020): 463-76. https:// doi.org/10.1080 /14733285.2019.1676879.

David C. Dollahite \& Loren D. Marks. "A Conceptual Model of Family and Religious Processes in Highly Religious Families." Review of Religious Research 50, no. 4 (2009): 373-91. https:// doi.org/www.js tor.org/stable/25593754.

Erwin Mahrus, Zaenuddin Hudi Prasojo, \& Busro. "Messages of Religious Moderation Education in Sambas Islamic Manuscripts." Madania: Jurnal Kajian Keislaman 24, no. 1 (2020).

Gillian England-Mason \& Andrea Gonzalez. "Intervening to shape children's emotion regulation: A review of emotion socialization parenting programs for young children." Emotion 20, no. 1 (2020): 98-104.

https:/ / doi.org/DOI:10. 1037/emo0000638.

Hermansyah. Ilmu Gaib di Kalimantan Barat. Jakarta: Kepustakaan Populer Gramedia, 2010.

- - - Islam dan Melayu di
Borneo. Pontianak: IAIN Pontianak Press, 2015.

Jalal Uddin, dkk. "adverse childhood experiences with children's mental health and attentiondeficit/hyperactivity disorder." Journal of Affective Disorders 272, no. 1 (2020): 104-9.

James N. Kirby. "Nurturing Family Environments for Children: CompassionFocused Parenting as a Form of Parenting Intervention." Education Sciences 10, no. 1 (2020): 1-15.

https:// doi.org/10.3390 /educsci10010003.

Jane Brooks. The Process Of Parenting. Yogyakarta: Pustaka Belajar, 2011.

M. Syahran Jailani. “Teori Pendidikan Keluarga dan Tanggung Jawab Orang Tua dalam Pendidikan Anak Usia Dini." Jurnal Nadwa: Jurnal Pendidikan Islam 8, no. 2 (2014): 245-56.

Masmuri \& Bayu Suratman. "Revitalisasi Masjid Dalam Membangun Karakter Pada Komunitas Melayu Sambas." jurnal intizar 25, no. 1 (2019). 
Michela Franceschelli \& Margaret $\quad \mathrm{O}^{\prime}$ Brien. "'Islamic Capital' and Family Life: The Role of Islam in Parenting." Sage Journal 48, no. 6 (2014): 1190-1206.

https:// doi.org/10.1177 /0038038513519879.

Moh.Haitami Salim. "Kontribusi Upacara Adat Mendirikan dan Pindah Rumah Terhadap Nilai Pendidikan Islam." Jurnal Walisongo: Jurnal Penelitian Sosial Keagamaan 21, no. 2 (2013): 331-36.

Rizal Mustansyir. Kearifan Lokal Masyarakat Melayu Sambas Dalam Tinjauan Filosofis. Yogyakarta: Fakultas Filsafat UGM, 2015.

Supaat \& Salmah Fa'atin. "The Muslim Millennial family typology: the role of Muslim family circumflex model to avoid parents' violent behavior against children in Indonesia." Indonesian Journal of Islam and Muslim Societie 9, no. 1 (2019): 57-81.

https:// doi.org/DOI: https:// doi.org/10.1832 6/ijims.v9i1.57-81.
Syamsul

Kurniawan. "Globalisasi: Pendidikan Karakter, dan Kearifan Lokal yang Hybrid Islam Pada Orang Melayu Kalimantan Barat." Jurnal Penelitian 12, no. 2 (2018).

Syamsul Kurniawan \& Bayu Suratman. "Bertani Padi Bagi Orang Melayu Sambas: Kearifan Lokal, Nilai-Nilai Islam, dan Character Building." Analisis: Jurnal Studi Keislaman 18, no. 2 (2018): 190-91.

Usang M Assim \& Julia SlothNielsen. African Human Rights Law Journal 14, no. 2 (2014): 322-45.

Valerie King. "The Influence of Religion on Fathers' Relationships With Their Children." Journal of Marriage and Family 65, no. 2 (2004): 382-95. https:// doi.org/10.1111 /j.17413737.2003.00382.x.

Van Lissa, Caspar J \& Keizer, Renske. "Mothers' and fathers' quantitative and qualitative parenting in relation to children's emotional adjustment: A between- and withinfamily investigation." Developmental

Psychology 56, no. 9 
Bayu Suratman \& Nurjannah.

(2020): 1709-22.

https:// doi.org/10.1037

/dev0001042.

Vani K. Borooah \& Sriya Iyer. "Vidya, Veda, and Varna: The influence of religion and caste on education in rural India." The Journal of Development Studies 41, no. 8 (2005): 1369-1404. https:// doi.org/10.1080 /00220380500186960.

Yusriadi. Identitas Orang Melayu di Hulu Sungai Sambas. Pontianak: IAIN Pontianak Press, 2017.

\section{- - - . Memahami Kesukubangsaan di Kalimantan Barat. Pontianak: STAIN Pontianak Press, 2008.}

\section{Zaenuddin Hudi Prasojo, Elmansyah, Muhammad Sahrin bin Haji Masri. "Moderate Islam and the Social Construction of Multi- Ethnic Communities in the Hinterland of West Kalimantan." Indonesian Journal of Islam and Muslim Societies." Indonesian Journal of Islam and Muslim Societie 9, no. 2 (2019): 218-19.}

Zairin Zain \& Indra Wahyu Fajar.
Konstruksi Rumah Tradisional Suku Melayu di Kota Sambas Kalimantan Barat." Jurnal Langkau Betang 1, no. 1 (2014): 18.

Zairin Zein. "The structural System of Tradisional Malay Dwellings in Sambas Town, West Kalimantan Indonesia." International Journal of the Malay World and Civilisation 30, no. 1 (2012): 139-58. 